\title{
Making Sense of Texts: A Meta-Analysis of College Students and Adults' Reading Strategies in a Hypermedia Environment
}

\author{
Cecille Marie Titar-Improgo ${ }^{1}$, Al Ryanne G. Gatcho ${ }^{2}$
}

${ }^{1}$ Bukidnon State University, the Philippines

${ }^{2}$ Trinity University of Asia

Corresponding author: Cecille Marie Titar-Improgo [cecillemarieimprogo@buksu.edu.ph]; Al Ryanne G. Gatcho [arggatcho@tua.edu.ph]

\begin{tabular}{llll}
\hline Received: 23.11.2020 & Accepted: 17.12.2020 & • Published: 29.12.2020
\end{tabular}

\begin{abstract}
With the information influx from the hypermedia environment, queries have been made on the reading landscape, markedly related to college and adult readers, as they are perceived to have limited experience with the hypermedia environment. This environment calls on new literacies for a reader to cope with reading tasks inherent to its features. In this context, new challenges have been posed regarding online reading strategies of college and adult readers. With the dearth of literature about how college and adult readers navigate their way in their reading tasks in the hypermedia environment, this paper described their strategies in reading. The information gathered from the studies conducted before can contribute to the present plight of our readers who need to navigate their way through reading in a hypermedia environment. Eight studies that met the criteria on the variables of the study were included. The studies revealed the following reading strategies of college and adult readers: global, problem-solving, local, cognitive and metacognitive, and navigation strategies. This evidenced that print-based reading strategies are basics on which reading strategies in the hypermedia environment are built for strategic readers to be successful in their online reading tasks.
\end{abstract}

Keywords: online reading strategies, hypermedia, college reader, adult reader, OSORS

\section{Introduction}

The proliferation of the use of technology has changed the reading landscape. Contrary to the times before hypermedia has invaded the literacy world, today, it is easier to retrieve information; instead, the challenge lies in distilling meaning (Bulger, 2006). Making sense of texts online entails multifarious tasks for the readers, as types of texts alone --- nonlinear, multiple-media, and interactive --- pose challenges for them (Coiro, 2003). Thus, the notion of new literacies (Leu, 2002) is introduced. Leu says, "The new literacies include the skills, strategies, and insights necessary to successfully exploit the rapidly changing information and communication technologies that continuously emerge in our world". Furthermore, the hypertext consumption of readers heightened as readers grapple to respond to the challenges posed by the COVID-19 pandemic, and such response paved to many challenges especially to those who are not accustomed to reading in a hypermedia environment (Lindner, Clemons, Thoron, \& Lindner, 2020). Moreover, hypermedia applications demand more from readers. Navigating hypertext, searching for information, filtering out unnecessary data, and monitoring daily change in the workplace arena are only a preview of what is to come in the 21 st century (Topic, 1992; Razak, Yassin, \& Maasum, 2020). It is then essential that 
readers possess strategies to maximize the technology so as to strategically make sense of texts the Internet has afforded them.

Reading in the hypermedia environment involves perusing digital texts, which differ from printed texts, in terms of the strategies it entails in processing the information from online texts. Although some are true to both media, others prove to be more restricted to online comprehension (Coiro \& Dobler, 2007; Spiro, 2004). For Chun (2001), hypertext, aside from being the same as regular text, comprises of links within the material to other documents or spots. Moreover, it grants nonsequential reading. This characteristic is because hypertexts can be put in storage, perused, explored, or modified. This feature engages the readers to make decisions, emphasizing strategies utilization as crucial in dealing with hypertext documents. Added to that, hypertext documents, when merged with audio or video may entail varied strategic processing (Leu \& Reinking, 1996, in Akyel \& Ercetin, 2009; Yassin, Razak, \& Maasum, 2019). Hence, Akyel and Ercetin (2009) claimed "readers may transfer their print-based reading skills to hypermedia reading but they will also need to use additional strategies characterized by the features of the environment".

In this context, the unsuspecting college and adult readers are faced with the perils that go with the hodgepodge of information and features that the Internet offers. There is a pressing problem, however, for the teachers, as to how they can possibly aid the college and adult readers to deal with what they are already confronted with in the hypermedia world, since "new electronic forms of text presentation appear to contain great potential for supporting readers as they interact with informational text, [but] relatively little work has been conducted to evaluate this potential for supporting reading comprehension" (Leu, Gallo, \& Hillinger, in press, p. 7). Reinking (1994) attests to this need, saying, "we need to understand more about the strategies that readers and writers use when reading and writing electronic texts" (p. 23). With the dearth of literature that explores the reading strategies that the reader in the hypermedia environment employ (Coiro, 2003), this paper aims to synthesize these works of literature and hopes to raise awareness on the online reading strategies that college and adult readers use.

Strategies, defined as the deliberate act of learners to serve its purpose, render prominence to the readers' active involvement in their selection and use. With a repertoire of reading strategies, the readers can face head on the gargantuan task of wading through the information available in just a click.

Most studies that investigated the college students' and adults' reading strategies in a hypermedia environment used the ones adapted by Anderson (2003) from the delineated reading strategies of Mokhtari and Sheorey (2002). They gave three categories: global, problem-solving, and support strategies. Global strategies are purposeful, where learners deliberately use to monitor their reading process. Problem-solving strategies are on how readers directly address difficult texts. Meanwhile, Support Strategies are the readers' own actions to aid their understanding of texts.

Congruent to the strategies of Mokhtari and Sheorey (2002) is the reading strategies categories, which are the cognitive and metacognitive strategies. Williams and Burden (1997) averred that: "Cognitive strategies are seen as mental processes directly concerned with the processing information in order to learn, that is for obtaining, storage, retrieval or use of information". Metacognitive strategies, meanwhile, are those for monitoring cognitive strategies.

The nomenclatures of common reading strategies can either be more "top-down" or "bottom-up". Top-down strategies, which readers employ to foretell the content of the reading material, create a reading target, and constantly assess own reading process, are labeled as general strategies (Block, 1986; Block, 1992; Cheng, 1998) or global strategies (Sheorey \& Mokhtari, 2001). Bottom-up 
strategies are those for comprehending specific linguistic units and are called local strategies (Block, 1986; Block, 1992) or problem-solving and support strategies (Sheorey \& Mokhtari, 2001).

Cognitive strategies encompass both local and global strategies. Local strategies are for bottomup processing or data-driven processing. These strategies cover determining word meaning, sentence structure, and letter-pronunciation connection (Konishi, 2003). Konishi added that global strategies are used in top-down processing. Top-down processing, also identified as conceptually-driven or reader-driven, includes text coherence and consistency. Also, it covers knowledge utilization on text structure, inferences, and background knowledge about text content. One category of strategies in ESL reading trend was created. Based on Mayes et al. (1990), navigation through hypertext learning systems, this category is labelled as navigational strategies. Readers use strategies to explore Web pages on the Internet. These strategies include scrolling up and down, switching from one page to another by clicking links or buttons, using multiple windows, and changing an active window.

\section{Materials and Methods}

This paper relied on the methodology of qualitative meta-data-analysis proposed by Paterson et al. (2001). They have evolved a multi-faceted approach to synthesis, dubbed as meta-study. Metadata analysis, which is an analysis of findings, was conceived similarly to Noblit and Hare's metaethnography. This type of data analysis is primarily interpretive and aims to disclose similarities and discrepancies among reports of a specific phenomenon. To achieve this paper's purpose, meta-dataanalysis is appropriate in order to arrive at a synthesis of college and adult readers' reading strategies in the hypermedia context.

Based on the steps of the meta-analysis, the following were done: (1) Identification, (2) Selection, (3) Abstraction, and (4) Analysis. The identification of studies and articles to be included was done through surfing the internet for articles and studies with the variables: Adult, College or University Students, Online Reading Strategies, Hypermedia Environment. From these, the articles and studies were filtered based on the criteria set, which are about the variables presented. Studies and articles that met these criteria were included in the paper. The abstraction of the findings was done by looking into the online reading strategies or reading strategies in the hypermedia environment. Findings that give online reading strategies were taken. Finally, data analysis was done. The basis of the analysis was on the reading strategies given by the aforementioned authors.

The Textual Narrative Synthesis is a part of this paper's method. It is an approach that groups homogenous studies so as to systematically look into their similarities and/or discrepancies. This approach tends to emphasize the heterogeneity of studies (Lucas et al., 2007), which is deemed appropriate in this qualitative meta-analysis.

\section{Results and Discussion}

The eight studies included in this paper have met the criteria based on the variables involved: adult, or college/university students, reading strategies, hypermedia environment. Table 1 is an overview of these studies. 
Table 1 . Summary on the reading strategies of college and adult readers in hypertext environment

\begin{tabular}{|c|c|c|c|c|c|}
\hline $\begin{array}{c}\text { Study } \\
\text { Number }\end{array}$ & $\begin{array}{c}\text { Proponents/ } \\
\text { Author }\end{array}$ & $\begin{array}{l}\text { Purpose of the } \\
\text { Study/ Paper }\end{array}$ & Context & Method & $\begin{array}{l}\text { Reading } \\
\text { Strategy }\end{array}$ \\
\hline 1 & $\begin{array}{l}\text { Amer, } \\
\text { Balwani, } \\
\text { T.A., } \quad \text { \& } \\
\text { Ibrahim, M. } \\
(2010)\end{array}$ & $\begin{array}{l}\text { Investigating online } \\
\text { reading strategies of } \\
\text { Omani EFL first, and } \\
\text { fourth year students }\end{array}$ & EFL & $\begin{array}{l}\text { Online Survey of } \\
\text { Reading Strategies } \\
\text { (OSORS, Anderson, } \\
\text { 2003, adapted from } \\
\text { Sheorey and } \\
\text { Mokhtari, 2001) }\end{array}$ & $\begin{array}{l}\text { Problem- } \\
\text { Solving } \\
\text { Strategy } \\
\text { Global } \\
\text { Strategy } \\
\text { Support } \\
\text { Strategy }\end{array}$ \\
\hline 2 & $\begin{array}{l}\text { Anderson, N. } \\
(2003)\end{array}$ & $\begin{array}{l}\text { Identifying online } \\
\text { reading strategies of } \\
\text { second language } \\
\text { readers }\end{array}$ & ESL & OSORS & $\begin{array}{l}\text { Problem- } \\
\text { Solving } \\
\text { Strategy } \\
\text { Global } \\
\text { Strategy } \\
\text { Support } \\
\text { Strategy }\end{array}$ \\
\hline 3 & $\begin{array}{l}\text { Cheng, R.T.J. } \\
\text { (2016). }\end{array}$ & $\begin{array}{l}\text { Determining } \\
\text { strategies of } \\
\text { language learners in } \\
\text { reading } \\
\text { materials }\end{array}$ & EFL & OSORS & $\begin{array}{l}\text { Problem- } \\
\text { Solving } \\
\text { Strategy } \\
\text { Global } \\
\text { Strategy } \\
\text { Support } \\
\text { Strategy }\end{array}$ \\
\hline 4 & $\begin{array}{l}\text { Huang, H.C., } \\
\text { Chern, C.L., } \\
\text { \& Lin, C.C. } \\
(2009)\end{array}$ & $\begin{array}{l}\text { Determining online } \\
\text { reading strategies of } \\
\text { EFL learners in } \\
\text { Taiwan }\end{array}$ & EFL & OSORS & $\begin{array}{l}\text { Support } \\
\text { Strategy } \\
\text { Problem- } \\
\text { Solving } \\
\text { Strategy }\end{array}$ \\
\hline 5 & $\begin{array}{l}\text { Jusoh, Z. \& } \\
\text { Abdullah, L. } \\
(2015)\end{array}$ & $\begin{array}{l}\text { Investigating the } \\
\text { extent of the use of } \\
\text { strategies when } \\
\text { reading online }\end{array}$ & $\begin{array}{l}\text { Academic } \\
\text { setting }\end{array}$ & $\begin{array}{lr}155 \quad \text { students } & \text { of } \\
\text { Languages } & \text { and } \\
\text { Communication } & \text { and } \\
\text { Information } & \text { and } \\
\text { Technology } & \\
\quad \text { OSORS } & \end{array}$ & $\begin{array}{l}\text { Problem } \\
\text { Solving } \\
\text { Strategies } \\
\text { Global } \\
\text { Strategies } \\
\text { Support } \\
\text { Strategies }\end{array}$ \\
\hline 6 & $\begin{array}{l}\text { Bland, J.H. } \\
(1995)\end{array}$ & $\begin{array}{l}\text { Identifying reading } \\
\text { strategies used by } \\
\text { adult readers as they } \\
\text { navigate through a } \\
\text { hypermedia } \\
\text { environment to read } \\
\text { informational text to } \\
\text { construct meaning }\end{array}$ & $\begin{array}{l}\text { Highly } \\
\text { technolo- } \\
\text { gical } \\
\text { workplace } \\
\text { setting }\end{array}$ & $\begin{array}{l}\text { Grounded theory was } \\
\text { developed as pieces } \\
\text { of information were } \\
\text { gathered from field } \\
\text { notes, observations, } \\
\text { questionnaires, } \\
\text { cognitive maps, and } \\
\text { interviews. }\end{array}$ & $\begin{array}{l}\text { Skimming } \\
\text { Checking } \\
\text { Reading } \\
\text { Responding } \\
\text { Studying }\end{array}$ \\
\hline
\end{tabular}




\begin{tabular}{|c|c|c|c|c|c|c|}
\hline \multirow[t]{5}{*}{7} & \multirow[t]{5}{*}{$\begin{array}{l}\text { Genc, } \\
(2011)\end{array}$} & \multirow[t]{5}{*}{ H. } & \multirow{5}{*}{$\begin{array}{l}\text { Investigating } \\
\text { metacognitive } \\
\text { reading strategies of } \\
\text { low-proficient EFL } \\
\text { learners while } \\
\text { reading paper-based } \\
\text { documents and } \\
\text { hypertext documents } \\
\text { for general } \\
\text { comprehension }\end{array}$} & \multirow[t]{5}{*}{ EFL } & \multirow{5}{*}{$\begin{array}{l}\text { Think-Aloud } \\
\text { Protocol }\end{array}$} & $\begin{array}{l}\text { Support } \\
\text { Strategy }\end{array}$ \\
\hline & & & & & & $\begin{array}{l}\text { Problem- } \\
\text { Solving } \\
\text { Strategy }\end{array}$ \\
\hline & & & & & & $\begin{array}{l}\text { Global } \\
\text { Strategy Using } \\
\text { background } \\
\text { knowledge }\end{array}$ \\
\hline & & & & & & $\begin{array}{l}\text { Monitoring of } \\
\text { not } \\
\text { understanding }\end{array}$ \\
\hline & & & & & & $\begin{array}{l}\text { Goal setting for } \\
\text { skimming }\end{array}$ \\
\hline \multirow[t]{4}{*}{8} & \multirow[t]{4}{*}{$\begin{array}{l}\text { Konishi, } \\
\text { (2003) }\end{array}$} & \multirow[t]{4}{*}{ M. } & \multirow{4}{*}{$\begin{array}{l}\text { Investigating the } \\
\text { strategies of ESL } \\
\text { learners when } \\
\text { reading through the } \\
\text { authentic pages on } \\
\text { the Internet }\end{array}$} & \multirow{4}{*}{$\begin{array}{c}6 \text { ESL } \\
\text { university } \\
\text { Japanese } \\
\text { students }\end{array}$} & \multirow{4}{*}{$\begin{array}{l}\text { Carrell (1989) and } \\
\text { Carrell (1998): } \\
\text { Cognitive and meta } \\
\text { cognitive strategies }\end{array}$} & $\begin{array}{l}\text { Local } \\
\text { Strategies }\end{array}$ \\
\hline & & & & & & $\begin{array}{l}\text { Global } \\
\text { Strategies }\end{array}$ \\
\hline & & & & & & $\begin{array}{l}\text { Meta-cognitive } \\
\text { Strategies }\end{array}$ \\
\hline & & & & & & $\begin{array}{l}\text { Navigational } \\
\text { Strategies }\end{array}$ \\
\hline
\end{tabular}

All eight studies contend that reading strategies employed by adults and college students in their print-based texts or when doing offline reading of texts are still summoned by these readers in the hypermedia environment. All of the eight studies also concur that the adult and college student readers also employ new strategies that are inherent to the hypermedia environment, in addition to their print-based reading strategies. The strategies are grouped based on the reading strategies delineated in the previous section: Based on the OSORS: Global, Problem-Solving, and Support Strategies; Local Strategies; Cognitive and Meta-Cognitive Strategies; and, Navigation Strategies.

\subsection{Offline Reading Strategies Employed in the Context of Hypermedia Environment}

Based on the findings of the eight studies, the following are the individual reading strategies employed by the adult and college readers involved in the study as they read in the hypermedia environment: global, problem-solving, support, local, cognitive and metacognitive, and reading strategies unique to the context of hypermedia environment. In this part of the paper, the previously established reading strategies common among printed text readers are presented in the context of the hypermedia environment.

\section{a. Global Strategies}

Common global strategies used by adult and college readers are making inferences, utilizing background knowledge, and having a purpose in mind. These strategies also include previewing, checking alignment of content and purpose, noting length and organization, and predicting the meaning of words. In the deeper aspect, reports of studies reveal that participants resort to guessing online text content.

As adults, participants bring past experiences and previous knowledge (schema) into the reading context. This was exhibited in most of the eight studies, with participants referring to their schema to understand the online text. With this context, and the purpose for reading in mind, they do 
categorizing, labelling what they read closely and what to ignore. They scan the online text to secure a preliminary idea of whether it is aligned to their purposes before choosing to read it.

As the environment allows it, the reader is provided with a vast array of choices to read based on the topic or "search word/phrase" entered. The reader then "filters" what link to click to further explore it, based on the title and the preliminary statements displayed. This is done against the purpose of the reader. From there, he makes a decision of whether to pursue certain links presented.

Participants employed several global strategies when they read online hypertext, and some of these are making inferences and connecting new information in the text with their background knowledge. From the results of their searches, they inferred from the title, background of the author, introductory statements, sources, and context of the article. Most of these activated their background knowledge. After which, they decided to pore over a hypertext and accommodate new information from it.

Most of the global strategies used were the same that readers utilized when they read the print text. These are strategies specifically applied in reading a single text carefully. However, some were on searching for information among hypertext with numerous text chunks linked one to another. Participants assessed the importance and the veracity of sources since they were tasked to search for information from various Web pages. This strategy calls for the reading skills of the reader. The ability to peruse and evaluate the veracity of an article is a higher reading skill. The hypermedia environment has provided the reader with the tools to be able to apply this reading strategy more quickly, in terms of the period needed for producing texts for it. Needless to say, their schema plays a pivotal role in their approach to reading texts online.

\section{b. Problem-Solving Strategies}

Leu, Kinzer, Coiro, and Cammack (2004) pointed out that reading online is like a process of solving problems where students need to reread to make sense of materials. This process was confirmed in that the participants used reading strategies through attempting to come up with what unknown words mean, pacing one's reading, imagining what the information looks like, meshing contradictory details, and reading again to increase understanding. They also used individual strategies of "trying to get back on track", and "reading slowly and carefully".

As foreseen in the feature of hypermedia, being non-linear, having help features and additional hyperlinks, reader-participants of the studies involved in this paper confessed to being distracted. When that happened, they tried to get back to their reading.

From the Think-Aloud verbalizations, the participants employed varied strategies in attacking difficult online texts. They said that they re-read them to increase their understanding, and concentrated on the material. Also, they read at an unhurried pace, thoroughly going through the text to ensure understanding the on-line material, once again, solving the problem by adjusting their reading speed. What also worked for the participants are guessing what the unknown words or phrases meant, attempting to discriminate fact from opinion, and trying to envisage information to remember the ideas taken from the texts.

\section{c. Support Strategies}

Support strategies like highlighting, looking up dictionaries, note-taking, or converting a text from one's native language to the target language were used for general comprehension. Using reference materials was also a strategy used by the adult and college reader-participants, based on the studies included in this meta-analysis. 
From the studies reviewed, the least popular strategies fall under the Support strategies. The reason for this outcome, according to Taki and Soleimani (2012), is that these strategies take much time to employ.

However, this set of reading strategies proved to work well with IT students. Most of them used more support strategies since they are more adept at internet features like online dictionaries and references. For this group, Support strategies gave them an advantage since it meant spending less time on text-decoding. They found support from the help features of the hypermedia environment in translating (word by word), using dictionaries (vocabulary as essential to understanding a text), and highlighting (to combat fear of losing information, due to the feature of online texts), to facilitate comprehension due to convenience and instant feedback in using them (Mokhtari \& Reichard, 2004).

\section{d. Local Strategies}

Local Strategies are also associated with Support Strategies. Most of the participants used Local strategies when they perused hypertext on-line. The participants employed these strategies by commenting on the word meaning, pronunciation, or grammatical interpretation. One participant, during the interview, commented that he was uncertain to have understood the article even after rereading a particular sentence many times over. The article he was reading was about a public execution in Thailand. His problem with the meaning of the sentence made him doubt whether the execution was made public or not.

\section{e. Cognitive Strategies and Meta-cognitive Strategies}

Strategies that are under the category of Cognitive strategies involve taking notes, summarizing, paraphrasing, and predicting. They also cover analyzing and using context clues (Singhal, 2001). Based on studies presented in this paper, cognitive behaviors exhibited when adults read printed text sometimes are duplicated in hypermedia text.

Strategies under Metacognitive involve cogitating over the learning process, planning, monitoring understanding, and assessing learning (Skehan, 1993, in Ozek \& Civelek, 2006).

New metacognitive reading strategies were displayed by the participants. They did slow, careful, and purposeful reading. They maximized data from the tables and figures and used their schema on the topic in the text. In addition, they monitored their understanding of the material and set goals for skimming as they were reading hypertexts.

Reports from studies reviewed in this paper showed that meta-cognitive strategies were effectively used as participants were perusing hypertexts. They had goals for reading. As they read along, they took notice of any difficulty and thus adjusted how they continued processing texts. The researchers noticed that some strategies included those which were used with printed materials. It was also noted that there were those who read hypertext with multimedia. Others skimmed and searched from more than a single page. The strategies participants displayed only drove the point that they were wellversed with the kind of reading they needed to do which redounded to their use of meta-cognitive strategies. With these findings, it is but necessary to look into various lenses when exploring online reading activities.

Skimming, a common offline reading strategy, is commonly exhibited by the participants even in the hypermedia context. Skimming was shown by going through text which was not common when studying or reading, as it was too fast for either of them. Participants utilized the page-up and page- 
down keyboard features, searching through the highlighted terms that were the designated keywords necessary to locate certain information (Coiro, 2011).

Checking, as a reading strategy, was done when going over the text. While at it, the individual was simply passively pouring over the material. It occurred when the participants slowed their reading speeds to scanning when they were simply glancing through descriptions in a scrolling mode. Reading was exhibited by going through text in an organized manner, reading a bit some of the pages but there was no attempt at using supporting resources. It was further exhibited when the electronic text stopped and the participants stopped screen movement to decide if the visible information completed the job task scenario.

Responding, in the form of tapping interactive resources available, and writing answers, was also displayed by the participants, specifically when they chose incorrect keywords that cause dead-end searches for the appropriate facts to complete the customer's order. Activating the wrong nodes prompted the reviewing behaviors in which the subjects activated new queries with different keywords. Finally, Studying was applied when the participants' eyes were systematically roving along with the text or going through text that has already been pored over, reading pages and/or visiting resources again (Bland, 1995).

Specific examples are that, as the employees were skimming and scanning through electronic text, some used the mouse pointer device in an S-like motion to guide their eyes down the screen. This reading technique resembles the use of a finger, hand, pencil, or other objects to guide the eye down a page when a person reading information printed in a paper format. Others utilized the straight edge of the screen to assist their eyes in left-to-right directionality across the wide electronic page. The reading technique resembles using a straight-edged object to support the left-to-right directionality of eye movement as the reader moves down a page in the traditional format. However, when dealing with more challenging texts, the more proficient ones monitored how they read through utilizing more complex metacognitive processing strategies (Huang, 1999) or applying schema (Shen, 2003).

\subsection{Reading Strategies Unique to the Context of Hypermedia Environment}

Reinking (1994b) describes features of texts in the hypermedia environment that college and adult readers are faced with. First, electronic texts can best be encapsulated with the word "fluidity". This describes the ability of texts to be viewed simultaneously, or move from one window to another. They also interact quickly with the reader's unique purpose. Second, the nonverbal elements, such as pictures, icons, graphics, movies, animations, and sounds, aid in comprehension. Among various comprehension support features are word definition, word pronunciation, animated explanation of the passage in question, useful background information, and, perhaps, a less technical version of the text displayed. Third, the nonlinear form of electronic literature, especially hypertext, invites the reader to journey through the digitized text on a personalized path. Fourth, the computerized text expands a reader's access to information through telecommunications and multiple databases. Electronic entry into sources beyond printed textbooks offers learners exciting research opportunities. Finally, the production capabilities of personal computers housed in classrooms through desktop publishing packages, e-mail facilities, and Internet availabilities are changing even the pragmatics and conventions of written communication. Electronic text not only provides input for readers, but it also allows a creative output for students to demonstrate concept attainment.

These features necessitate the use of online reading strategies so that the readers can maximize them. Hence, the readers employ new strategies particularly in reading hypertext. The reading 
strategies that epitomize this is Navigation, borrowed from the area of human-computer interactions (Mayes et al., 1990).

\subsection{Navigational Strategies}

Highly technology-literate participants exhibited some examples of the navigational strategies. Konishi (2003) reported in his study that one participant clicked a link but was not led to the expected page. It was noted that she did not become irate, but decided instead to read another page quickly. The researchers revealed that the experience was already common to her that she got used to things like that to happen when she navigated the Internet before.

In the same study of Konishi (2003), he narrated the experience of a participant who was supposed to look at the picture upon clicking a link. Apparently, the picture that did not appear was deemed by the participant to aid her in understanding the text that she thought was quite difficult. She succeeded after a series of attempts at reloading. The researcher noted that the participant was accustomed to the situation and thus was able to cope with it using her favorite browser software.

Another example was given by Konishi (2003) where a participant was adept at keeping multiple windows open. She compared the information on several pages which were kept open and decided which ones to close or to remain open.

Finally, the nagivational strategy was displayed in reference to a highlighted link of a Web page. This feature means that the link has been visited already. However, as reported, one participant thought he had not actually gone through the page before. Although he was hesitant, he still decided to click the link to visit the page.

The unique behaviors shown by the participants above are inherent in reading in a hypermedia environment. The participants displayed familiarity with hypertext features. With hypertext systems' electronic nodes and links, they naturally possess connectivity and intertextuality (Ebersole, 1997; Hunter, 1998; Rouet, Levonen, Dillon, \& Spiro, 1996; Snyder, 1996). Hypertext also has features of multi-linearity and open-endedness (Kaplan, 1995; Landow, 1992). Since text chunks are interconnected, there are several ways of reading through hypertext. Because it is not meant to be linear, reading hypertext necessitates continual assimilation of new information and monitoring of understanding. It is the readers' decision to make as to what topic to access and in what sequence they would go through the pages by clicking links. As reported, this strategy was shown by the participants when they presented hyperlinks and had to decide whether to follow these links or continue reading the text they started with.

In a nutshell, the reading strategies called for in the hypermedia environment are illustrated in Figure 1. The studies have proven that adult and college readers, in order to survive in today's society, have to be equipped with the new literacies so as to optimally function. The new literacies are built upon the offline or print-based reading strategies that are supposedly possessed already by these adult and college readers. 


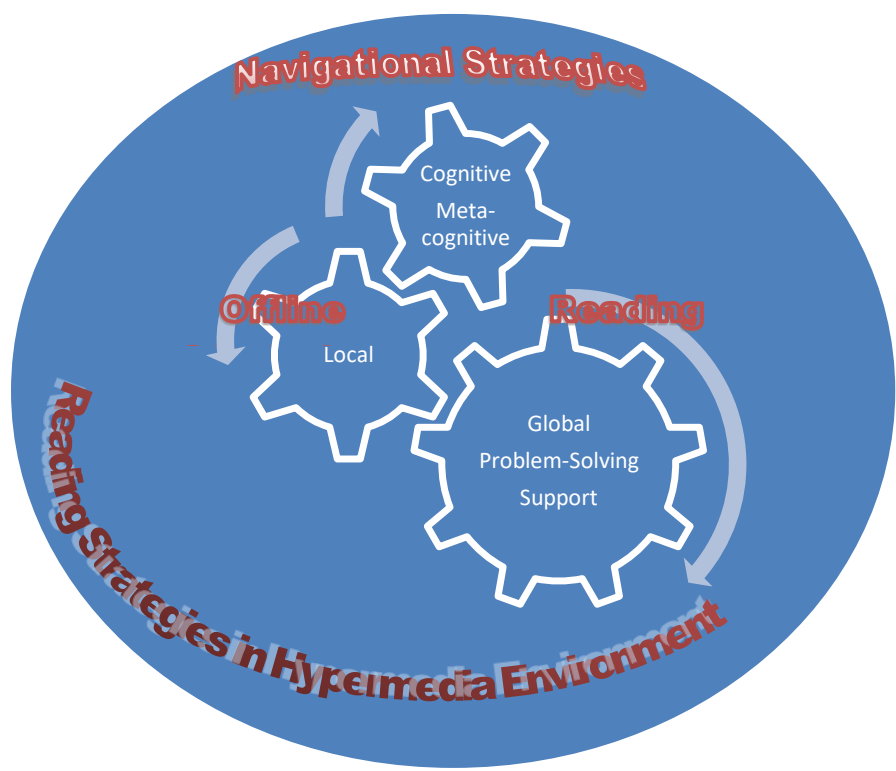

Figure 1. The Offline Reading Strategies as Core towards Reading Strategies in Hypermedia Environment

The offline reading strategies serve as basics for the adult and college readers before they can competently involve themselves in reading in the hypermedia environment. The studies have proven that the print-based reading strategies interact and overlap in the course of reading. When the readers are equipped with these core reading strategies, there is hope that they can tackle online reading tasks. As the difficulty level of online reading tasks increases, the readers have more reasons to tap their repertoire of reading strategies. With these basic strategies built in them, they can accommodate the new literacies and the navigational strategies that the hypermedia environment necessitates them to possess.

\section{Conclusion and Implications}

As the studies in this paper have posited, readers in the hypermedia environment are equipped with a vast repertoire of strategies. They adeptly use them to accomplish the reading goals they have set. This study described how adult and college readers navigate through online texts inherent in a hypermedia environment to construct meaning.

Readers demonstrated the use of diverse strategies. Among them are cognitive strategies, which include Local and Global strategies, meta-cognitive, and navigational strategies. If readers are adequately equipped with high cognitive flexibility because of well-developed print-based reading strategies, they can enjoy reading in another perspective that is only experienced in a hypermedia environment. With hypertext reading, readers can easily widen their interests with a simple tap or click at links. Readers will enjoy the quick pace that they are led into a series of information.

Results of this meta-analysis can significantly contribute to the ever-changing pedagogical landscape of reading teachers as they increase their knowledge of the reading repertoire of hypermedia readers. With the ever-advancing technology that permeates the society, the reading teachers are faced with the daunting tasks of building up the print-based reading strategies and gradually scaffold readers towards online reading strategies. In doing so, the college and adult readers of the future generation can imbibe the new literacies and be strategic in their approach to online reading tasks. On this note, teachers of reading need to explicitly teach print-based reading strategies. The building-up and establishing well the print-based strategies among readers would impact how they would comprehend various texts as they navigate the hypertexts in the hypermedia environment. The challenge for reading 
teachers is therefore posed: develop the print-based reading strategies of the students so that they would be equipped to navigate the intricate web of on-line information.

As this meta-analysis paper is on hypertext reading and the pandemic has brought about an increased emphasis on online education at all levels, it is recommended that further studies be conducted with the variables explored in this paper. Further research can be done as to the effectiveness of the reading strategies employed in the hypertext environment in terms of attaining reading comprehension. It can also include participants of the younger generation who are more familiar with navigational skills.

\section{References}

Amer, A., Balwani, T. A., \& Ibrahim, M. (2010). Student teachers' perceived use of online reading strategies. International Journal of Education and Development using Information and Communication Technology (IJEDICT), 6(4)4, 102-113.

Anderson, N. (2003). Scrolling, clicking, and reading English: Online reading strategies in a second/foreign language. The Reading Matrix, 3 (3), 460-472.

Akyel, A., \& Ercetin, G. (2009). Hypermedia reading strategies employed by advanced learners of English. System Journal, 37, 136-152.

Bland, J.H. (1995). How adult readers navigate through expository text in a hypermedia environment to construct meaning. Unpublished dissertation. University of North Texas.

Block, E. (1986). The comprehension strategies of second language readers. TESOL Quarterly, 20, 163-194.

Block, E. (1992). See how they read: Comprehension monitoring of L1 and L2 readers. TESOL Quarterly, 26, 319-342.

Bulger, M. (2006). "Beyond Search: A Preliminary Skill Set for Online Literacy". The Transliteracies Project: Research in the Technological, Social, and Cultural Practices of Online Reading.

Cheng, R.T.J. (2016). Reading online in foreign languages: A study of strategy use. International Review of Research in Open and Distributed Learning, 17(6).

Chun, D. M. 2006, CALL technologies for L 2 reading. CALICO Monograph Series, 5, 69-98.

Coiro, J. \& Dobler, E. 2007, Exploring the online reading comprehension strategies used by sixthgrade skilled readers to search for and locate information on the Internet. Reading Research Quarterly, 42 (2), 214-257.

Foltz, P. W. (1993). Readers' comprehension and strategies in linear text and hypertext. Dissertation Abstracts International. 54(31).

Genc, H. (2011). Paper and Screen: Reading Strategies Used by Low-Proficient EFL Learners. SinoUS English Teaching, ISSN 1539-8072 October, 8(10), 648-658. 
Huang, H.C., Chern, C.L., \& Lin, C.C. (2009). EFL learners' use of online reading strategies and comprehension of texts: An exploratory study. Computers and education, 52(13), 13-26.

Jusoh, Z. \& Abdullah, L. (2015). Online Survey of Reading Strategies (OSORS): Students' Online Reading in Academic Context. Malaysian Journal of Distance Education 17(2), 67-81.

Konishi, M. (2003). Strategies for reading hypertext by Japanese ESL learners. The Reading Matrix, $3(3), 97-118$.

Leu, D. J., Gallo, M. J., \& Hillinger, M. L. (in press). Reading comprehension in hypermedia: Reconsidering the nature of considerate text within dynamic, electronic environments.

Leu, D.J., Kinzer, C.K., Coiro, J., Cammack, D., 2004, Toward a theory of new literacies emerging from the internet and other ICT. In: Ruddell, R.B., Unrau, N. (Eds.), Theoretical Models and Processes of Reading. International Reading Association, Newark, DE, pp. 1568-1611.

Leu, D.J., Reinking, D., 1996, Bringing insights from reading research to research on electronic learning environments. In: van Oostendorp, H., de Mul, S. (Eds.), Cognitive Aspects of Electronic Text Processing. Ablex Publishing, Norwood, NJ, pp. 43-75.

Lindner, J., Clemons, C., Thoron, A., \& Lindner, N. (2020). Remote instruction and distance education: A response to COVID-19. Advancements in Agricultural Development, 1(2), 53-64.

Madhumathi, P. \& Ghosh, A. (2012). Awareness of Reading Strategy Use of Indian ESL Students and the Relationship with Reading Comprehension Achievement. English Language Teaching; Vol. 5, No. 12; 2012 ISSN 1916-4742 E-ISSN 1916-4750 Published by Canadian Center of Science and Education.

Mokhtari, K., \& Sheorey, R. (2002). Measuring ESL students' awareness of reading strategies. Journal of Developmental Education, 25(3), 2-10.

Paterson, B. L., Thorne, S. E., Canam, C., \& Jillings, C. (2001). Meta-study of qualitative health research: A practical guide to meta-analysis and meta-synthesis. London: Sage publications.

Razak, N. A., Yassin, A. A., \& Maasum, T. N. R. T. M. (2020). Formalizing Informal CALL in Learning English Language Skills. In Enhancements and Limitations to ICT-Based Informal Language Learning: Emerging Research and Opportunities (pp. 161-182). IGI Global.

Reinking, D. (1994a, December). Literacy in a post-typographic world. Paper presented at the annual meeting of the National Reading Conference. San Diego, CA.

Reinking, D. (1994b) Electronic Literacy. Athens, GA: University of Georgia.

Rouet, J.-F., Levonen, J. J., Dillon, A., \& Spiro, R. J. (Eds.). (1996). Hypertext and cognition. Lawrence Erlbaum Associates, Inc.

Sheorey, R., and Mokhtari, K. (2001). Differences in the metacognitive awareness of reading strategies among native and non-native readers. System, 29, 431-449. 
22 Titar-Improgo et al. (2020): Making Sense of Texts: A Meta-Analysis of College Students and Adults' Reading Strategies in a Hypermedia Environment

Taki, S. and Soleimani, G. (2012). Online reading strategy use and gender differences: The case of Iranian EFL learners. Mediterranean Journal of Social Sciences, 3(2), 171-181.

Yassin, A. A., Razak, N. A., \& Maasum, N. R. M. (2019). Investigating the Need for Computer Assisted Cooperative Learning to Improve Reading Skills Among Yemeni University EFL Students: A Needs Analysis Study. International Journal of Virtual and Personal Learning Environments (IJVPLE), 9(2), 15-31. 